\title{
Supramolecular Complexation of Sulfonated Aluminum Phthalocyanines and Chitosan in the Mixed Aqueous Solutions
}

\author{
I. M. Lipatova, ${ }^{\circledR}$ E. A. Chernova, and A. A. Yusova \\ G.A. Krestov Institute of Solution Chemistry of the Russian Academy of Sciences, 153045 Ivanovo, Russia \\ Corresponding authorE-mail: i_lipatova@bk.ru
}

\begin{abstract}
By spectrophotometry and dynamic light scattering methods, the self-assembling processes in mixed aqueous solutions of second-generation photosensitizer Photosens (hydroxyaluminum trisulfophthalocyanine) and chitosan were investigated. It was established, that in dilute aqueous mixtures the Photosens and chitosan form supramolecular complexes with reproducible stoichiometric composition in these conditions, what corresponds the molar ratio of chitosan:Photosens = 2.3:1. It was found, that phthalocyanine in the composition of these supramolecular complexes presents in the form of $\mathrm{H}$-and J-aggregates. Ability of chitosan to bind Photosens reduces with decrease of molecular weight of chitosan. The influence of $\mathrm{pH}$ and the presence of disaggregating additives on the complexation process of Photosens with chitosan was considered.
\end{abstract}

Keywords: Chitosan, sulfonated phthalocyanines, photosensitizer, electrostatic self-assembling, supramolecular complexes.

\section{Супрамолекулярное комплексообразование сульфированных фталоцианинатов алюминия и хитозана в смешанных водных растворах}

\author{
И. М. Липатова, ${ }^{\circledR}$ Е. А. Чернова, А. А. Юсова \\ Федеральное государственное бюджетное учреждение науки Институт химии растворов им. Г.А. Крестова \\ Российской академии наук, 153045 Иваново, Россия \\ ${ }^{\circledR}$ E-mail: i_lipatova@bk.ru
}

\begin{abstract}
Методами спектрофотометрии и динамического светорассеяния исследованы процессы самоорганизации в смешанных низкокониентрированных водных растворах фотосенсибилизатора второго поколения Фотосенса (трисульфофталоцианин гидроксиалюминий) и хитозана. Установлено, что в смешанных водных разбавленных растворах Фотосенс и хитозан образуют супрамолекулярные комплексы с воспроизводимым стехиометрическим составом, что соответствует молярному соотношению хитозан:Фотосенс=2.3:1. Фталоциинин в составе образующихся супрамолекулярных комплексов с хитозаном присутствует в форме H- и J-агрегатов. Способность хитозана связывать Фотосенс убывает с уменьшением молекулярной массы хитозана. Рассмотрено влияние рН и присутствия дезагрегирующих добавок на прощесс комплексообразования Фотосенса с хитозаном.
\end{abstract}

Ключевые слова: Хитозан, сульфированный фталоцианин, фотосенсибилизатор, электростатическая самосборка, супрамолекулярный комплекс. 


\section{Introduction}

Interest to phtalocyanines as objects of research in recent years continues to grow. Particular attention is given to metallocomplexes of phthalocyanines due to the continuous expansion of their application areas. ${ }^{[1,2]}$ Metallophthalocyanines and their supramolecular aggregates are used as dyes, catalysts, photosensitizers, chemosensors, and components of electrochemical devices. One of the most significant areas of application of metallophthalocyanines is their use as photosensitizers for diagnosis and photodynamic therapy of cancer. ${ }^{[3-5]}$ Among such compounds, the Photosens drug, representing the hydroxyaluminum average trisulfophthalocyanine, is well known and widely used in clinical practice. [3,6-8] Using of the photosensitizers was related to the problem of toxicity. Therefore, the search of methods for their immobilization on biocompatible carriers for subsequent release into the affected area is conducted. ${ }^{[1,9-11]}$ In particular, the possibility of introduction of Photosens in hybrid nanostructures based on the complex of water-soluble polycationic derivative of fullerene $\mathrm{C}^{6} 0^{[10]}$ and its reversible immobilization on chitosan nanofibres ${ }^{[11]}$ and on the calcium acetate particles ${ }^{[12]}$ is investigated. Soluble synthetic polycation is branched polyethyleneimine, ${ }^{[9]}$ and also interpolyelectrolyte spherical capsules $^{[13]}$ were proposed to use as carriers of sulfonated aluminum phthalocyanines. According to the hypothesis of the authors of cited works, various forms of drug binding in hybrid structures help to reduce toxicity and increase efficiency of its action as a photodynamic agent. Sulfonated phthalocyanines molecules in aqueous solutions are negatively charged over a wide $\mathrm{p} H$ range. The presence of charge allows them to enter into supramolecular assemblies with the cationic carrier, forming in the electrostatic self-assembly mode. The use of cationic polysaccharide of natural origin of chitosan as a carrier may be of considerable interest. Chitosan is a biocompatible, biodegradable polymer, having a film- and fiberforming properties. Physical and chemical properties of chitosan are described in details. ${ }^{[14,15]}$ There are works on non-covalent interactions of chitosan with amphiphilic macroheterocyclic compounds, having sulfo-groups as peripheral substituents. ${ }^{[16-18]}$ In particular, the processes of supramolecular self- assembling, involving chitosan and tetrasulfophenylporphyrin in aqueous solutions, ${ }^{[17]}$ and also the conditions of formation of insoluble complex in these systems were investigated. ${ }^{[18]}$ However, the studies of the processes of supramolecular complexation in mixed aqueous solutions of chitosan with sulfo-substituted metallophthalocyanines were not carried out.

The aim of this work was the spectrophotometric study of the process of supramolecular complexation of chitosan with sulfonated hydroxyaluminum phthalocyanines on the example of Photosens drug.

\section{Experimental}

Industrial chitosan (Sigma-Aldrich (USA)) with averageviscosity molecular weight (MM) of 195000 and a deacetylation degree of 0.85 according to the potentiometric titration was used. Low molecular weight chitosan samples were obtained by peroxide depolymerization as described in. ${ }^{[19]} \mathrm{MM}$ of chitosan samples was determined by viscometric method, using the equation of MarkKuhn-Houwink: $[\eta]=K \cdot \mathrm{M}_{\alpha}$. For chitosan $K=1.464 \cdot 10^{-4} ; \alpha=0.885$ in acetate buffer solution. ${ }^{[20]}$

Photosens was kindly supplied by the Institute of Organic Intermediates and Dyes (Moscow, Russia). This photosensitizer is a mixture of sulfonated aluminum phthalocyanines with different degrees of sulfonation $(n=2,3$, and 4). It exhibits a $679 \mathrm{~nm}$ absorbance peak and can induce the generation of reactive oxygen species at an energy of $\sim 100 \mathrm{~J} / \mathrm{cm}^{2}{ }^{\left[{ }^{[6]}\right.}$

Averaged content of sulfo-groups per one molecule of phthalocyanine, determined by elemental analysis, is 3 .

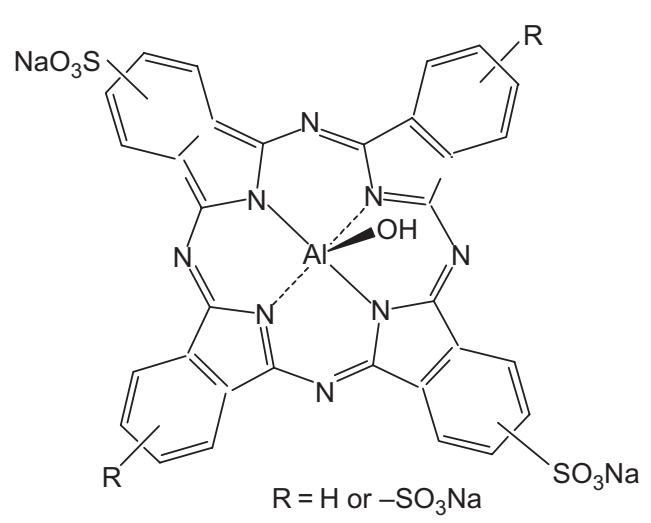

Scheme 1.

UV-vis absorption spectra of aqueous solutions were recorded on a spectrophotometer "CARY 100" in the wavelength range $300-900 \mathrm{~nm}$ at $\mathrm{pH}=4.0 \pm 0.1$. The treatment of the spectra was performed using the program "CARY 100 SCAN". Standard glass cuvettes with an optical path length $(l)$ of $10 \mathrm{~mm}$ and $1 \mathrm{~mm}$ were used. The $\mathrm{pH}$ in the solutions was adjusted by adding $0.1 \mathrm{~N} \mathrm{NaOH}$ or $\mathrm{HCl}$ solutions.

The particle size of the chitosan-phthalocyanine complexes was determined by dynamic light scattering method, the $\zeta$-potential by electrophoretic light scattering on the analyzer of particles size and zeta-potential Zetasizer Nano, («Malvern Instruments Ltd», UK). The measurements were performed immediately after the mixing components and diluting a dispersion by water $(1: 15)$ at $\mathrm{p} H=4.0 \pm 0.1$.

Fluorescence emission spectra were recorded on a spectrofluorimeter Avaspec 2048-2 (Avantes).

Elemental composition of the drugs was determined on the chromatographic analyzer Flash HCNS-0 EA 1112, “Termo Quest” (Italy).

\section{Results and Discussion}

Chitosan (CS), polyaminosaccharide represents an unbranched chain, which consists of $\beta$ - $(1 \rightarrow 4)-2$-amino-2deoxy-D-glucan residues:

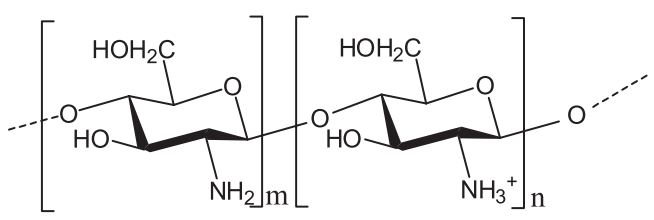

Environments in the $\mathrm{p} H$ range from 4.0 to 6.0, at which the polymer and the macrocycle are present in solution in ion- 
ized condition, were used. Chitosan in weakly acidic solutions is a polycation due to protonation of the amino-groups, and has apparent constant of dissociation of conjugate acid the $\mathrm{p} K_{\mathrm{a}}=6.3-6.4{ }^{[14]}$ Photosens in a wide $\mathrm{p} H$ range exhibits anionic properties because sulfo-derivatives of aromatic compounds are strong acids.

It is known that sulfo-substituted metallo-phthalocyanines in aqueous solutions are capable to self-association due to hydrophobic and $\pi$ - $\pi$-electron intermolecular interactions. ${ }^{[21-23]}$ In the case of sulfonated hydroxyaluminum phthalocyanines, the presence of axial hydroxyl ligand and a distortion of the macrocycle planarity with a yield of the aluminum atom from the plane prevents the realization of stackinginteraction. Therefore, these macrocycles retain monomeric state in aqueous solutions of up to relatively high concentrations of the order of $10^{-3} \mathrm{M} \cdot{ }^{[24]}$

In the visible region of absorption spectra Photosens has an intense $Q$-band with a maximum at $679 \mathrm{~nm}$, which can be attributed to $a_{1 u}(\pi) \rightarrow\left(\pi^{*}\right)$ transition and vibronic band of low intensity at $607 \mathrm{~nm}$ (Figure 1, spectrum 1). Soret band ( $B$-band), located at a wavelength of $350 \mathrm{~nm}$, can be attributed to $\mathrm{a}_{2 \mathrm{u}}(\pi) \rightarrow\left(\pi^{*}\right)$ transition. ${ }^{[25]}$

Figure 1 shows the UV-vis absorption spectra of aqueous solutions, containing the same concentrations of Photosens and increasing the number of CS in the range of molar ratios of polymer to the phthalocyanine (CS:Pc) from 0 to $6: 1$. In increasing the concentration of chitosan, a decrease in intensity of the Soret band, $Q$-band and its vibrational satellite at $607 \mathrm{~nm}$ is observed. Reducing the intensity of the major bands in the presence of CS is accompanied by some increase in the absorption in 620-640 $\mathrm{nm}$ range. Such spectral changes can indicate aggregation of $H$-type macrocycles. ${ }^{[13,26,27]}$ On the other hand, a significant increasing absorption is observed in the region of 700-800 $\mathrm{nm}$. The increasing absorption in this area is attributed to the formation of poorly studied $J$-aggregates of phthalocyanines. ${ }^{[28-30]}$ $\mathrm{In}^{[28]}$ an increasing absorption in 700-800 $\mathrm{nm}$ was observed upon formation of complexes $\mathrm{Al}(\mathrm{OH}) \mathrm{PcS}_{4}$ with cationic surfactants. It is also reported the formation of $H$ - and $J$ aggregates of aluminum phthalocyanine (AlClPc), adsorbed on the surface of silica nanoparticles. ${ }^{[30]}$ In our case, it can be

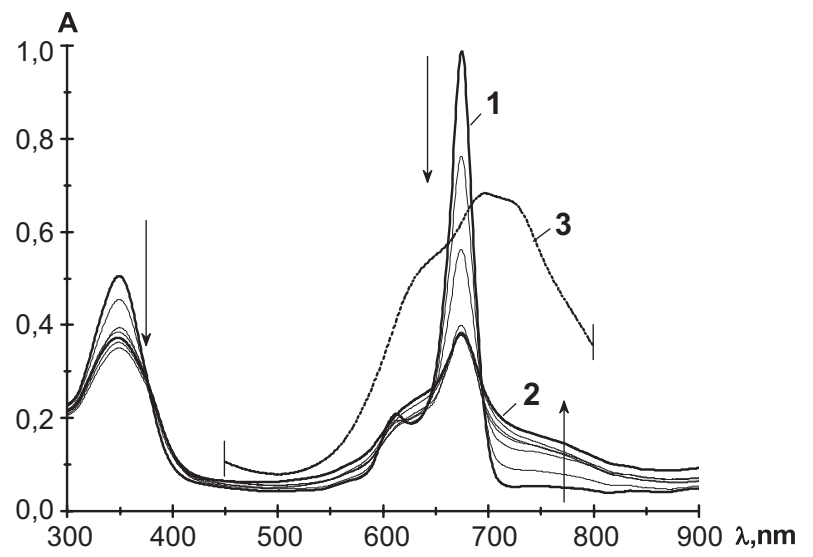

Figure 1. UV-vis absorption spectra of Photosens solutions $\left(C_{\mathrm{Pc}_{\mathrm{c}}}=1 \cdot 10^{-5} \mathrm{M}\right)$ in mixtures with chitosan upon increasing CS:Pc from 0 to $6: 1 ; \mathrm{pH}=4.0 .1$ - Photosens; 2 - complex CS Pc; 3 - solid phase Photosens. assumed, that high local concentrations of phthalocyanine, leading to the formation of higher order associates, arise due to electrostatic interaction near the polymer.

For sulfosubstituted metallophthalocyanines, not having axial ligands, the formation of higher order associates can be fixed via the electronic absorption spectra of aqueous solutions with a significant increase in the concentration or salt-induced self-association. ${ }^{[31]}$ For hydroxyaluminum sulfophthalocyanines with a very low propensity to the association, watching formation of associates in solution using absorption spectra is not possible. Therefore, to receive absorption spectra of the associated Photosens, his samples were prepared by drying the solutions on the slides, which were used for recording solid phase spectrum (Figure 1, spectrum 3). The resulting spectrum is a superposition of spectra, bathochromic and hypsochromic shifted relative to the $Q$ band of Photosens in solution. The position of the bands in the solid spectrum corresponds to regions of increasing the absorption at transformation of absorption spectra of Photosens in mixtures with CS (620-640 nm and 700-800 nm). This confirms that the interaction of Photosens with CS leads to multimeric aggregation of phthalocyanine on polymer.

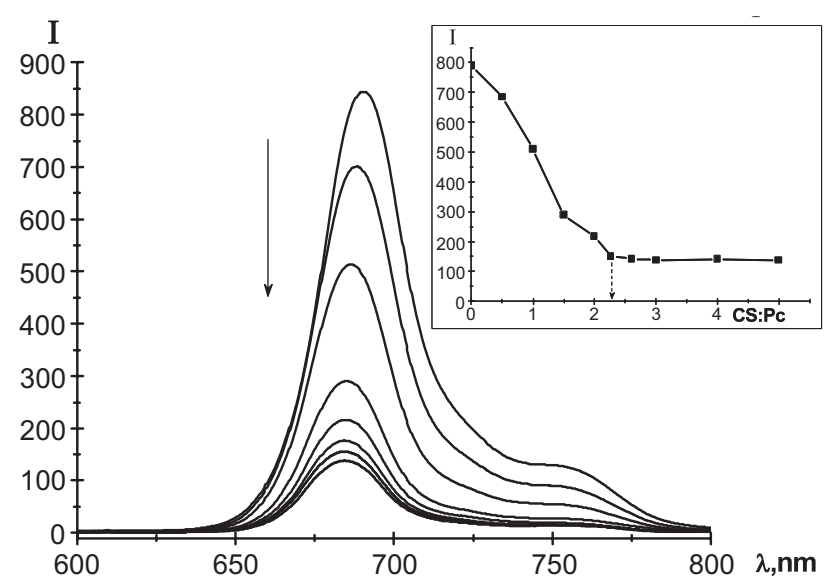

Figure 2. The change in the fluorescence emission spectra of Photosens in mixtures with chitosan upon increasing CS:Pc from 0 to $6: 1$; excitation at $\lambda=350 \mathrm{~nm}$. Inset: Dependence of fluorescence intensity on the molar ratio of CS:Pc in solution.

After reaching a certain molar ratio of CS:Pc in a mixed solution the form of the absorption spectra of Photosens did not change with further increase of the content of CS (Figure 1, spectrum 2). This demonstrates the full binding of phthalocyanine by chitosan to form a supramolecular complex. Character of final spectrum of Photosens indicates the presence in the supramolecular complex with chitosan three forms of phthalocyanine: $H$-aggregates, $J$-aggregates and monomers.

Hydroxyaluminum sulfophthalocyanines, included in the Photosens composition, are fluorophores, highly sensitive to the intermolecular interactions. It is known that phthalocyanine aggregates, due to the annihilation of the excited states, do not fluoresce. ${ }^{[32,33]}$ Upon the introduction of chitosan in Photosens aqueous solution the decrease in fluorescence intensity is observed (Figure 2). After reaching a molar ratio $(\mathrm{CS}: \mathrm{Pc}=2.3: 1)$ the decreasing fluorescence 
intensity is discontinued, however, complete quenching is not observed. This confirms the presence of the monomeric form of phthalocyanine in the composition of complex with CS. Our interpretation of data on the fluorescence quenching of Photosens in the presence of CS is different from conclusions, ${ }^{[34]}$ in which complexation of sulfonated aluminum phthalocyanines with protein (cytochrome $c$ ) was studied. In the cited paper, the aggregation of phthalocyanine was not recorded using the absorption spectra, and fluorescence quenching, according to the authors, occurs exclusively due to photo-induced electron transfer reactions with phthalocyanine on protein.

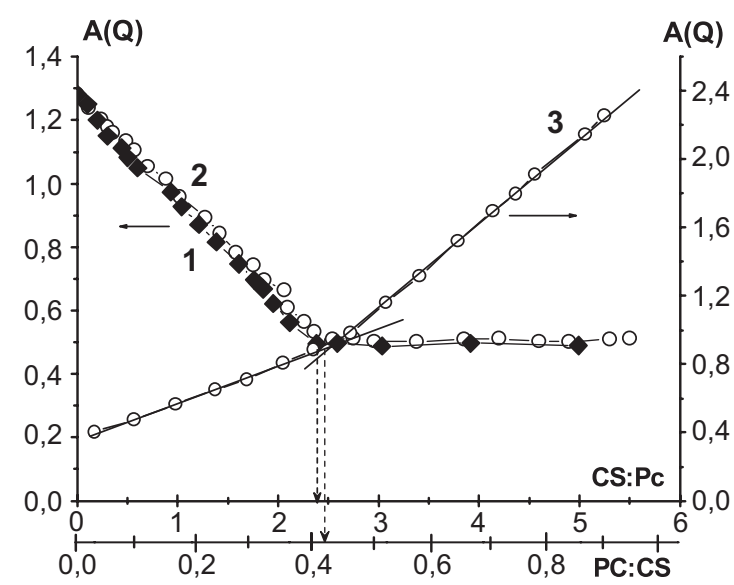

Figure 3. Titration curves of Photosens by chitosan (axis CS:Pc): $1-C_{\mathrm{Pc}}=1 \cdot 10^{-5} \mathrm{M}, l=10 \mathrm{~mm} ; 2-C_{\mathrm{Pc}}=1 \cdot 10^{-4} \mathrm{M}, l=1 \mathrm{~mm} ; 3$ - titration curve of chitosan by Photosens (axis Pc:CS), $C_{\mathrm{Pc}_{\mathrm{c}}}=1 \cdot 10^{-5} \mathrm{M}$.

The average stoichiometric composition of the complex, formed in solution, was determined by spectrophotometric titration of Photosens by CS in water. The inflection point with transition to the horizontal on titration curves corresponds to the total binding phthalocyanine by polymer. The projection of the inflection point on the composition axis corresponds to a mole ratio of polyelectrolyte and the macrocycle in forming complex. For two concentrations of phthalocyanine, which differ by an order, the equivalence points coincide (Figure 3, curves 1 and 2). Figure 3 also shows the titration curve of chitosan by phthalocyanine solution. Composition of the mixture is expressed ratio of Pc:CS. When recalculation on the ratio of CS:Pc, the same composition of the resulting complex was received, as well as in the case of titration by chitosan. Thus, the stoichiometric composition of forming supramolecular complex in aqueous mixtures of chitosan and Photosens is reproducible and does not depend on the concentration of components in the mixtures, and the component, which is present in excess. Under our experimental conditions ( $\mathrm{pH}=4.0$; $C=2 \cdot 10^{-3} \mathrm{M} ; \mathrm{MM}=195000$ ), the composition of the complex corresponds to a mol ratio of $\mathrm{CS}: \mathrm{Pc}=2.3: 1$. It should be noted, that this ratio is an average value and is a superposition of relations for sulfonated hydroxyaluminum phthalocyanines, included in the Photosens. In our case, the fact of reproducibility of the resulting composition is important, that allows to predict the full binding of the drug, based on the introduced CS concentration.
Investigation of the influence of molecular weight $\mathrm{CS}$ (MM) on its ability to complexation with Photosens is one of the tasks in this work. As shown by spectrophotometric titration data, for high molecular samples of CS with MM>100 000 the significant difference in the ability to bind Photosens was not observed. For low molecular samples of CS, obtained by peroxide depolymerization, ${ }^{[19]}$ a significant reduction of the ability to complexation with Photosens was found. This is manifested in the fact, that the molar ratio of CS:Pc in the complexes with decreasing MM is increased, i.e. more chitosan is required for full binding of equimolar amounts of Photosens. A similar pattern was found for other systems based on polyelectrolytes and oppositely charged amphiphilic compounds. ${ }^{[35,36]} \mathrm{In}^{[35]}$ it is shown, that low molecular samples of chitosan in aqueous solutions exhibit significantly greater flexibility, than high molecular samples, which are characterized by the formation of more rigid asymmetric structures. Probably, the most accessibility of amino groups for interaction with the phthalocyanine molecules in CS samples with more MM is explained more rigid conformation of its macromolecules.

Table 1. Influence of $M M$ of chitosan on the characteristics of supramolecular complexes with Photosens.

\begin{tabular}{ccccc}
\hline № & MM CS & CS:Pc & d, nm & $\xi, \mathrm{mV}$ \\
\hline 1 & 210000 & 2.5 & 340 & +22 \\
2 & 195000 & 2.4 & 290 & +24 \\
3 & 18800 & 3.3 & 180 & +18 \\
4 & 2000 & 6.0 & 120 & +14 \\
\hline
\end{tabular}

Table 1 shows the values of molar ratios of CS:Pc in supramolecular complexes CS·Photosens for used CS samples with different MM. Average size (d) and values of $\xi$-potential ( $\mathrm{pH}=5.0$ ) of supramolecular complexes, formed in mixed solutions of Photosens and chitosans of different MM, were determined by dynamic light scattering.

As the investigated process proceeds in the electrostatic self-assembly mode, an important factor is the $\mathrm{pH}$ of the mixed solution. The role of $\mathrm{pH}$ is caused by his influence on degree of dissociation of charge-carrying groups of CS and phthalocyanine.

Figure 4(a) shows the titration curves of the Photosens solution by chitosan at different $\mathrm{p} H$ values. The expected increase in the molar ratio of CS:Pc in the composition of the resulting complexes was obtained with increasing the $\mathrm{pH}$. This pattern is associated with the fact, that the protonation degree of amino groups of CS and, accordingly, the number of binding sites is reduced with increasing $\mathrm{pH}$. For used in the experiment $\mathrm{pH}: 4.0 ; 5.0$ and 6.0, the protonation degree of amino groups of chitosan was 1.0 ; 0.85 and $0.61^{[37]}$ and the obtained molar ratio of $\mathrm{CS}: \mathrm{Pc}$ in the complexes was $2.3: 1 ; 2.7: 1$ and $3.4: 1$, respectively. The position of the horizontal plots of the titration curves and character of the limiting spectra, corresponding to these plots (Figure 4b), indicates that the proportion of monomeric phthalocyanine molecules is increased with increasing $\mathrm{pH}$ in the composition of the resulting complexes. This can be explained by the fact, that the charge on macromolecules 

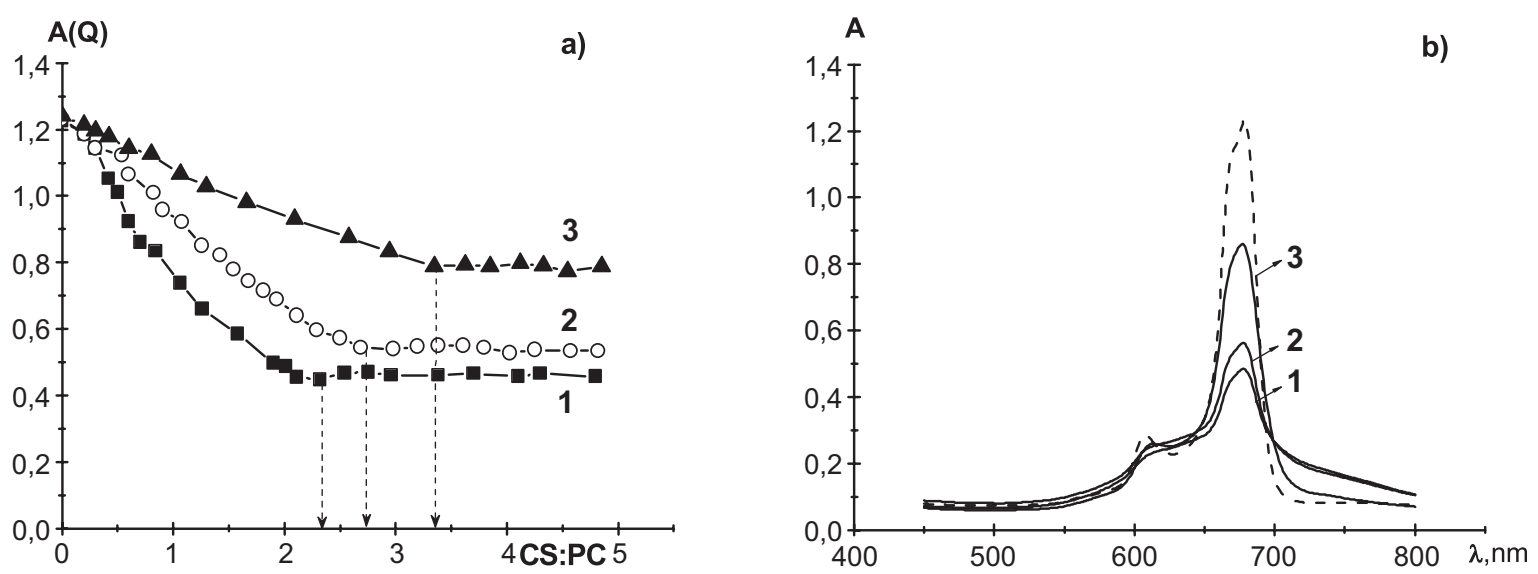

Figure 4. Titration curves of Photosens by chitosan (a) and the limiting absorption spectra of mixtures (b) at $\mathrm{p} H: 4.0$ (1); 5.0 (2) 6.0 (3); dotted line - absorptionn spectra of free Photosens.

of $\mathrm{CS}$ is decreased with increasing $\mathrm{pH}$, that is accompanied by compressing and a decreasing the internal space of macromolecular coils. Reducing a charge of CS contributes to the increasing role of hydrophobic interactions and hydrogen bonds between the Photosens and polymer, involving monomeric forms of phthalocyanine.

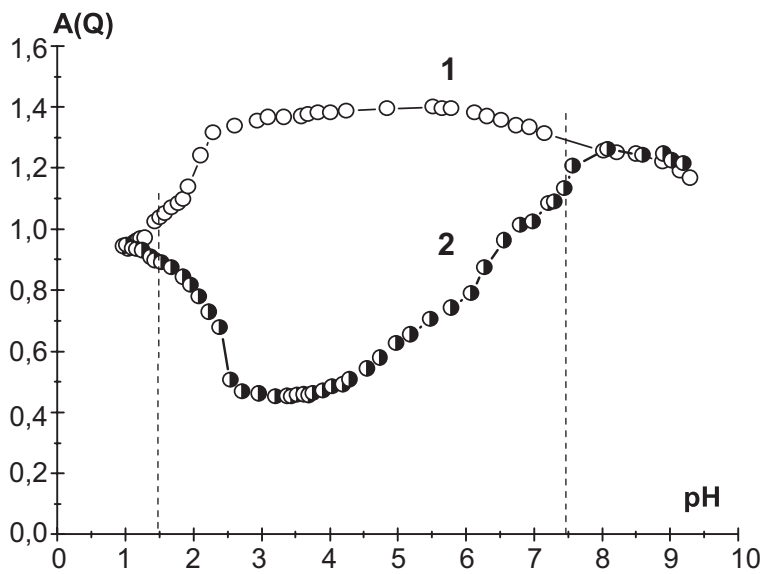

Figure 5. Dependences of absorbance $A(\mathrm{Q})$ on the $\mathrm{p} H$ of initial Photosens (1) and its complex with CS (2).

To determine the $\mathrm{pH}$-range of existence of the CSPhotosens complex, the dependences of absorbance A(Q) on the $\mathrm{pH}$ for initial Photosens (Figure 5, curve 1) and its complex with CS (Figure 5, curve 2) were recorded in parallel. The combination of the obtained dependences indicates the destruction of the complex. As it follows from the data of Figure 5, the full release of the phthalocyanine is achieved at $\mathrm{pH}>7$. The values, at which the dissociation degree of the sulfogroups in the phthalocyanine molecules is sharply reduced, are a lower limit of the $\mathrm{pH}$ of complexation. According to our experiments, $\mathrm{p} H=1.5$ corresponds to this value of lower limit, which is consistent with the literature data on the dissociation constants of aromatic sulfonic acids (according to different sources, $\left.\mathrm{p} K_{\mathrm{a}}=0.5-1.0{ }^{[31]} \mathrm{p} K_{\mathrm{a}}=2.6\right) .^{[38]}$ Thus, the range of $1.5<\mathrm{p} H<7.5$ is a condition of existence of supramolecular CS-Photosens complexes. The fact, that the upper limit of existence of the complex exceeds isoelectric point of chitosan is a characteristic.

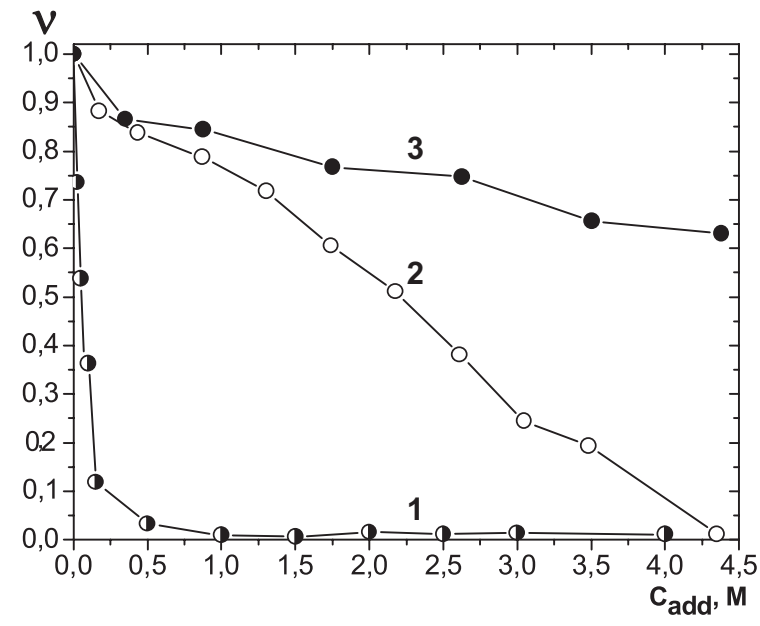

Figure 6. The dependence of binding degree of Photosens by chitosan on the concentration of introduced additives: $1-\mathrm{NaCl} ; 2$ - urea; 3 - ethanol.

Destruction of the complex can be caused by an increase in ionic strength of solution or introducing disaggregating additives. We investigated the effect of introducing a salt $(\mathrm{NaCl})$, and disaggregating agents (urea and ethanol) in $\mathrm{CS}$ and Photosens mixed solutions. The ratio of components in the mixtures was constant $(\mathrm{CS}: \mathrm{Pc}=2.5: 1)$ and corresponded to the totally binding phthalocyanine in the complex with CS in the absence of additives. The introduced additives in the used concentration range do not affect the intensity of the $Q$-band $\left(A_{0}\right)$ of free phthalocyanine. Figure 6 shows the effect of additives concentration on the binding degrees of phthalocyanine $(v)$, which was calculated from the spectrophotometric data by the formula: ${ }^{[39]}$

$$
v=\frac{A_{0}-A}{A_{0}-A_{\infty}},
$$

where $A_{0}-A_{\infty}$ is limit decreasing intensity of $Q$-band at fully binding phthalocyanine. 
The addition of salt, which already at $1 \mathrm{M}$ concentration causes a complete release of the Photosens, showed the strongest dissociating effect. Introduction of strong electrolyte inhibits complexation with chitosan due to the weakening electrostatic interaction between the anionic sulfonic groups of phthalocyanine and positively charged protonated amine groups of $\mathrm{CS}$. Urea causes the complete destruction of the complex at a concentration of $4.5 \mathrm{M}$, and ethanol at the same concentration causes release of phthalocyanine only by $35 \%$. There is a perception that the supramolecular complexes of polyelectrolytes with amphiphilic macrocyclic compounds were stabilized not only by electrostatic interactions, but also hydrophobic, $\pi$ - $\pi$-interactions between small molecules. ${ }^{[17,40]}$ The contribution of the non-electrostatic interactions, apparently, should decrease with decreasing capacity of macrocyclic compound to self-assembly in water. In our case the phthalocyanine, as noted above, has very low ability to self-association. The decisive role in the complexation process of Photosens with chitosan belongs to electrostatic interaction, which is confirmed by experimental data.

\section{Conclusion}

By spectrophotometric method it was established that supramolecular complexes, containing polymer and phthalocyanine in the form of $H$ - and $J$-aggregates, are formed in the mixed dilute aqueous solutions of chitosan and sulfonated hydroxyaluminum phthalocyanines in the self-assembly mode. The ability of chitosan to complexation reduces with decreasing molecular weight. Complexation takes place in the medium, corresponding to the $1.5<\mathrm{p} H<7.5$ range. Introduction of electrolyte or disaggregating additives promotes the dissociation of the complexes with the release of phthalocyanine.

Acknowledgments. This work was supported by RFBR (grant 16-03-00135a). This work was carried out with the help of the centre of the scientific equipment collective use «The upper Volga region centre of physicochemical research». The authors are grateful to Prof. E.A. Lukyanets (Institute of Organic Intermediates and Dyes, Moscow, Russia) for providing Photosens and for his valuable help.

\section{References}

1. Baulin V.E., Tsivadze A.Y., Gol'dshleger N.V. Protection of Metals and Physical Chemistry of Surfaces 2014, 50, 135.

2. Lukyanets E.A., Nemykin V.N. J. Porphyrins Phthalocyanines 2010, 14, 1-40.

3. Lukyanets E.A. J. Porphyrins Phthalocyanines 1999, 3, 424.

4. Tao X., Ma W.H., Zhang T.Y., Zhao J.C. Angew. Chem. Int. Ed. 2001, 40, 3014.

5. Josefsen L.B., Boyle R.W. Metal-Based Drugs 2008, 23.

6. Allison R.R., Downie G.H., Cuenca R.E., Hu X.-H., Childs C.J., Sibata C.H. Photodiagn. Photodyn. Ther. 2004, 1, 27.

7. St. Denis T.G., Huang Y.Y., Hamblin M.R. Cyclic Tetrapyrroles in Photodynamic Therapy. In: Handbook of Porphyrin Science, Vol. 27, 2014, p. 283.
8. Shirmanova M.V., Zagainova E.V., Sirotkina M.A., Snopova L.V., Balalaeva I.V., Krutova I.M., Lekanova N., Turchin I.V., Orlova A.G., Kleshnin M.S. J. Biomed. Opt. 2010, 15(4), 048004-1-048004-8.

9. Baek S.Y., Na K. J. Colloids Surf., B: Biointerfaces 2013, 101, 493.

10. Kotel'nikov A.I., Rybkin A.Y., Goryachev N.S., Belik A.Y., Kornev A.B., Troshin P.A. Dokl. Phys. Chem. 2013, 2, 229.

11. Severyukhina A.N., Petrova N.V., Smuda K., Terentyuk G.S., Klebtsov B.N., Georgieva R., Bäumler H., Gorin D.A. Colloids Surf., B: Biointerfaces 2016, 144, 57.

12. Svenskaya Yu., Parakhonskiy B., Haase A., Atkin V., Lukyanets E., Gorin D., Antolini R. Biophys. Chem. 2013, 182, 11.

13. Zeng Y., Wang X-L., Yang Y-J., Chen J-F., Fu J., Tao X. Polymer 2011, 52, 1766.

14. Muzzarelli R.A.A., Muzzarelli C. Adv. Polym. Sci. 2005, 186, 151.

15. Rinaudo M. Prog. Polym. Sci. 2006, 31, 603.

16. Guibal E., Roussy J. React. Funct. Polym. 2007, 67, 33.

17. Synytsya A., Král V., Volka K., Blafková P., Ederová J., Spěvaček J., Slepička P. Biomacromolecules 2009, 10, 1067.

18. Synytsya A., Synytsya A., Blafkova P., Volka P., Kral V. Spectrochim. Acta, Part. A 2007, 66, 225-235.

19. Mezina E.A., Lipatova I.M. Russ. J. Appl. Chem. 2015, 88, 1576

20. Wang W., Bo S., Li S., Qin W. Int. J. Biol. Macromol. 1991, 13, 281.

21. Snow A.W. Phthalocyanine Aggregation. In: Porphyrin Handbook, Vol. 17 (Kadish K., Smith K., Guilard R., Eds.). Elsevier Science, 2003, p. 129.

22. Cruen L.C., Blagrove R.J. Aust. J. Chem. 1973, 26, 319.

23. Abel E.W., Pratt J.M., Whelan R. J. Chem. Soc. Dalton. Trans. 1976, 6, 509

24. Juzenas P., Juzeniene A., Rotomkis R., Moan J. J. Photochem. Photobiol., B 2004, 75, 107.

25. Leznoff C.C., Lever A.B.P. Phthalocyanines Properties and Applications. New York: VCH Publishers, Inc, 1989, $436 \mathrm{p}$.

26. Wang W.Z., Wang R., Zhang C., Lu S., Liu T.X. J. Polymer 2009, 50, 1236

27. Kotiaho A., Lahtinen R., Efimov A., Metsberg H-K., Sariola H., Lehtivuori N., Tkachenko V., Lemmetyinen H. J. Phys. Chem. C 2010, 114, 162.

28. Correia R.F., Andrade S.M., Viseu M.I. J. Photochem. Photobiol., $A$ 2012, 235, 21.

29. César A., Laia T., Sílvia M., Costa B. J. Phys. Chem. B 2008, $112,4276$.

30. Lobanov A.V., Sultimova N.B., Levin P.P., Meshkov I.B., Melnikov M.Ya. Macroheterocycles 2015, 8, 279.

31. Ahrens U., Kuhn H.Z. Phys. Chem. Neue Folge 1963, 37, 1.

32. Zhang X.F., Xi Q., Zhao J. J. Mater. Chem. 2010, $20,6726$.

33. Edrei R., Gottfrid V., Van Lier J.E., Kimel S. J. Porphyrins Phthalocyanines 1998, 2, 191.

34. César A., Laia T., Sílvia M., Costa B., Phillips D., Beeby A. J. Phys. Chem. B 2004, 108, 7506.

35. Davydova V.N., Ermak I.M., Gorbach V.I., Drozdov A.L., Solov`eva T.F. Biofizika 2000, 45(4), 641-647.

36. Lipatova I.M., Makarova L.I., Mezina E.A. Russ. J. Gen. Chem. 2016, 86, 2226.

37. Rinaudo M., Pavlov G., Desbrieres J. J. Polymer 1999, 40, 7029 .

38. Ohno O., Kaizu Y., Kobayashi H. J. Chem. Phys. 1993, 99, 4128.

39. Marshall A.G. Biophysical Chemistry: Principles, Techniques, and Applications. New York: Wiley, 1978, 1(3B).

40. Peyratout C., Daehne L. Phys. Chem. Chem. Phys. 2002, 4, 3032. 